\title{
Clethra concordia (Clethraceae), a Shrubby New Species from the Crest of the Cordillera del Cóndor on the Peru-Ecuador Border
}

\author{
David A. Neill \\ Universidad Estatal Amazónica, Facultad de Ingeniería Ambiental, km 2¹⁄2 vía a Napo, \\ Puyo, Pastaza, Ecuador. davidneill53@gmail.com \\ Hamilton Beltrán \\ Herbario USM, Museo de Historia Natural, Universidad Mayor Nacional de San Marcos, \\ Casilla 14-0434, Lima 14, Peru. wilmersantiago@hotmail.com
}

\section{Wilson Quizhpe}

Herbario LOJA, Universidad Nacional de Loja, Facultad de Ciencias Agrícolas, Casilla 11-01-249, Loja, Ecuador.wwquizhpe@yahoo.es

Abstract. Clethra concordia D. A. Neill, H. Beltrán \& Quizhpe (Clethraceae), a thin-stemmed shrub or treelet from the sandstone Machinaza plateau in the Cordillera del Cóndor region on the Peru-Ecuador border, is described and illustrated. The new species is distinct from other species of Clethra L. in its small stature and its very small, thick sclerophyllous leaves, which are evidently an ecological adaptation to the highly acidic, nutrient-poor sandstone substrate where it occurs.

Resumen. Se describe y se ilustra Clethra concordia, D. A. Neill, H. Beltrán \& Quizhpe (Clethraceae), un arbusto o arbolito con tallos delgados, procedente de la meseta de Machinaza, de roca arenisca, en la región de la Cordillera del Cóndor en la frontera entre Perú y Ecuador. La especie nueva se distingue de las demás especies de Clethra L. en su estatura pequeña y en las hojas muy pequeñas, gruesas y esclerófilas, las que evidentemente constituyen una adaptación al substrato de arenisca muy ácido y pobre en nutrientes, en donde se encuentra esta especie.

Key words: Clethra, Clethraceae, Ecuador, IUCN Red List, Peru.

Clethra L. is a widespread genus with ca. 70 to 80 species distributed in warm temperate areas and tropics of the Western Hemisphere from the southeastern United States to southern Brazil, in warm temperate and tropical eastern Asia from southern China to Malaysia, and on the Atlantic island of Madeira (Sleumer, 1967; Hamilton, 1985; Fior et al., 2003). Clethra has traditionally been considered the sole genus in Clethraceae, but recent evidence (Anderberg \& Zhang, 2002) suggests that the Neotropical genus Purdiaea Planch. should be placed in Clethraceae rather than its traditional position in Cyrillaceae. Within Clethra, about 45 species are found in the Neotropics, from Mexico south to southern Brazil and northern Argentina, mostly in montane forests of the Mesoamerican isthmus and in the tropical Andes. Nine species have been reported for Ecuador (Gustafsson, 1992) and 11 species for Peru (Brako \& Zarucchi, 1993). All of the Neotropical species are placed in Clethra sect. Cuellaria (Ruiz \& Pav.) DC., characterized by the evergreen, persistent leaves and the flowers with stamens and styles included. Most of the Neotropical Clethra species are mid-sized canopy or subcanopy trees, attaining at least $10 \mathrm{~m}$ in height, although some species are found in flower or fruit as shrubs of 3-5 m in height, particularly those species that grow at high elevations or at forest edges.

The Cordillera del Cóndor is an eastern outlier of the main Andean chain that extends about $150 \mathrm{~km}$ from north to south and forms part of the international border between southeastern Ecuador and northern Peru. The geology of the Cóndor range is complex; one of the sedimentary strata that make up the Cóndor is the crystalline sandstone Hollín formation of mid-Cretaceous age, which has been uplifted and exposed with the rise of the Andes in the last 3 to 4 million years (Gregory-Wodzicki, 2000) to form a discontinuous series of flat-topped or inclined plateaus, sandstone fragments that vary in size from a few hectares to $20-30 \mathrm{~km}^{2}$ in size, at elevations from $300 \mathrm{~m}$ to ca. $2900 \mathrm{~m}$. The soil derived from the crystalline white quartzsite bedrock of the Hollín formation is highly acidic and very poor in $\mathrm{N}, \mathrm{P}, \mathrm{K}$, and other nutrients essential for plant growth, so as in other areas with oligotrophic white sand or sandstone- 
derived soils, the vegetation on the sandstone plateaus of the Cóndor is relatively low in stature, and many of the plants that grow there have relatively small, thick, coriaceous, and sclerophyllous leaves (Neill, 2005).

The sandstone outcrops at $2000 \mathrm{~m}$ elevation and higher in the Cordillera del Cóndor generally have a dense, low scrublike vegetation, ca. $3 \mathrm{~m}$ tall, or lower at higher elevations. Some of the shrubby dominants with thick sclerophyllous leaves in this vegetation are locally endemic species of genera that normally are mid-size canopy or subcanopy trees in Andean cloud forests; an example is Weinmannia L. (Cunoniaceae) for which three dwarf, shrubby species with small sclerophyllous leaves, locally endemic to the Cordillera del Cóndor, have been described recently (Rogers, 2002a, 2002b) in this genus of mostly Andean trees. We describe herein another example in the genus Clethra, a species known from just one sandstone plateau fragment of the Cordillera del Cóndor that is very distinctive in its small stature and small sclerophyllous leaves.

Clethra concordia D. A. Neill, H. Beltrán \& Quizhpe, sp. nov. TYPE: Ecuador. Zamora Chinchipe: Cantón Centinela del Cóndor, Cordillera del Cóndor, Machinaza plateau summit area, adjacent to obelisk-shaped border marker, at end of trail from upper Paquisha military post, precisely at Ecuador-Peru border, $2400 \mathrm{~m}$, $03^{\circ} 53^{\prime} 50^{\prime \prime} \mathrm{S}, 78^{\circ} 28^{\prime} 49^{\prime \prime} \mathrm{W}, 15$ Mar. 2008 (fl., fr.), D. Neill \& W. Quizhpe 16200 (holotype, QCNE-222802; isotypes, AAU, F, GB, HUT, K, LOJA, MO, NY, QCA, QCNE, US, USM). Figures 1, 2.

Haec species a congeneris statura minore, foliis reductissimis rigidis crassis coriaceis usque ad $1.8 \mathrm{~cm}$ longis ad apicem dentibus 1 ad 9 gracilibus praeditis atque inflorescentia terminali racemosa solitaria recedit.

Thin-stemmed shrubs or treelets, to $2 \mathrm{~m}$ tall, but flowering and fruiting at $1 \mathrm{~m}$ tall or less, often with a single, unbranched erect trunk $2-3 \mathrm{~cm}$ diam., or with a few erect or ascending branches terminating in erect inflorescences. Leaves borne erect on erect or steeply ascending branches, or on the unbranched trunk, the blades of adjacent leaves overlapping and clasping the branch; leaves very stiff and brittle, coriaceous and sclerophyllous, the blade elliptic, ovate or slightly obovate, $0.9-1.5(-1.8) \times 0.4-0.8$ $\mathrm{cm}$, apex obtuse or acuminate, base obtuse; margin entire along the basal $2 / 3$, usually with 3 to 9 prominent slender marginal teeth $1-1.5 \mathrm{~mm}$ long along the apical $1 / 3$ of the blade, each marginal tooth

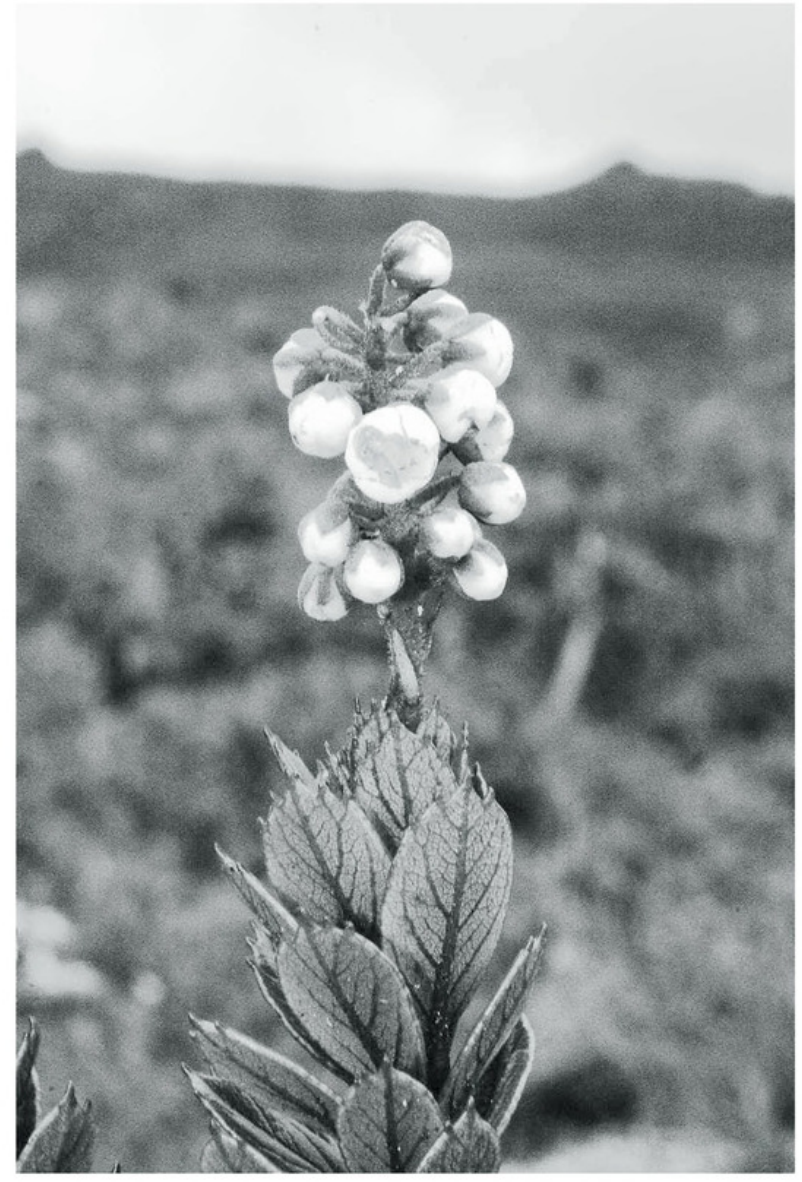

Figure 1. Clethra concordia D. A. Neill, H. Beltrán \& Quizhpe, growing in scrub vegetation at the type locality on the Machinaza plateau at $2400 \mathrm{~m}$ elevation. Photo by David Neill.

terminating a lateral vein, sometimes entire except for a single apical tooth; adaxial surface glabrous or with a few scattered stellate hairs on young leaves, so glabrescent, abaxial surface glabrous or with a few simple unbranched hairs along the costa and margin; costa impressed above, prominent below, 3 to 5 pairs of lateral veins, prominulous on both surfaces or sometimes rather inconspicuous, the veins often reddish on fresh leaves. Inflorescence a compact raceme, terminal and erect on erect leafy branches, 2-3 cm, with up to 15 flowers per raceme; inflorescence axis, bracts and pedicels minutely tomentose with reddish brown stellate hairs, bracts linear-subulate, 4-6 mm; pedicels to $7 \mathrm{~mm}$. Sepals 5 , ovate, $3 \times 2 \mathrm{~mm}$, broadly acute at apex, truncate at base; adaxial surface glabrous or with scattered unbranched hairs; abaxial surface densely tomentose with inner layer of minute stellate hairs and outer one of larger, unbranched fasciculate hairs, the indument reddish brown; petals 5 , white, broadly obovate, $5 \times 3$ $\mathrm{mm}$, broadly rounded at apex, truncate at base, slightly cucullate, imbricate at anthesis, forming an 


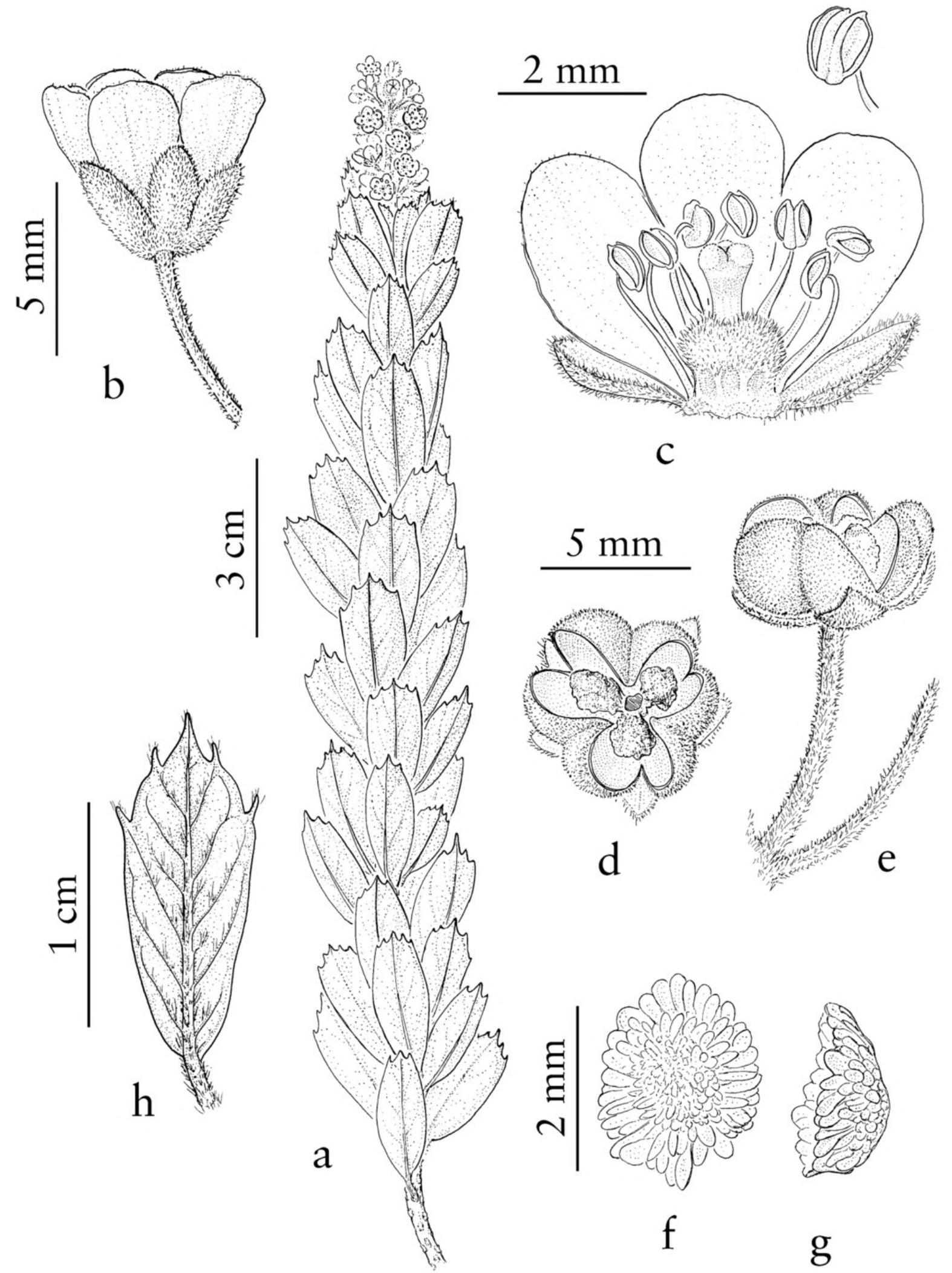

Figure 2. Clethra concordia D. A. Neill, H. Beltrán \& Quizhpe. - A. Erect flowering branch with erect inflorescence. -B. Flower, side view. - C. Flower interior showing stamens and pistil. -D. Dehisced fruit, top view. - E. Dehisced fruit, side view. -F. Seed, top view. - G. Seed, side view. —H. Leaf. Drawn from Beltrán \& Foster 1501 (MO).

urceolate corolla open at the apex, and later opening more widely to form an open cupular corolla; stamens 10 , filaments $3 \mathrm{~mm}$, anthers yellow, ca. $1 \mathrm{~mm}$, ovary densely pubescent with minute stellate reddish brown hairs, style ca. $1 \mathrm{~mm}$, bluntly 3 -lobed. Capsule 3valved, 2-3 $\mathrm{mm}$ long, $4-5 \mathrm{~mm}$ diam., to $6-7 \mathrm{~mm}$ diam. after dehiscence, minutely puberulent with stellate hairs; seeds broadly elliptic, compressed, ca. 
$2 \times 1 \mathrm{~mm}$, with a lacerate wing formed by inflated cells of the testa.

Distribution and ecology. Clethra concordia is known from just two localities, one in Ecuador and one in Peru, about $7 \mathrm{~km}$ apart on the summit of the nearly level Machinaza plateau. This is one of the largest and highest of the sandstone plateaus in the Cordillera del Cóndor, and it sits astride the international border. The western part of the plateau, on the Ecuadorian side, is in the watershed of the Río Machinaza, a tributary of the Río Zamora; the eastern portion, on the Peruvian side, is in the watershed of the Río Comainas, a tributary of the Río Cenepa that drains into the Río Marañón; the watershed boundary is hardly recognizable on this flat plateau, but it constitutes the international border. The entire Machinaza plateau, mostly at $2300-2400 \mathrm{~m}$, but dipping to about $2150 \mathrm{~m}$ at the eastern margin, covers an area of ca. $15 \mathrm{~km}^{2}$, and comprises the only known area of occurrence and suitable habitat for $C$. concordia. The vegetation on this plateau is a low, rather sparse scrub, with shrubs mostly less than 1.5 $\mathrm{m}$ tall. Among the shrubby species that co-occur with C. concordia is Weinmannia condorensis Z. S. Rogers, another example of a low, shrubby plant with very small, sclerophyllous leaves whose congeners are mostly Andean trees with larger, thinner, more mesophyllous leaves. Several other shrubs in various plant families at this site are believed to be locally endemic species not yet known to science (Neill, pers. obs.). Fragments of charred stems indicate that the area was burned over in the past, probably in the 1980 s or early 1990s. There are other sandstone plateaus in the Ecuadorian portion of the Cordillera del Cóndor, mostly below $2000 \mathrm{~m}$ elevation, with a somewhat taller and denser scrub vegetation, but $C$. concordia has not been found at any other locality.

The adaptive advantage of thick, stiff, sclerophyllous leaves, which Clethra concordia shares with many other species that are edaphically restricted to oligotrophic white-sand or sandstone-derived soils, appears to be related to protection from herbivory, since the loss of hard-won leaf tissue would threaten the survival of the plant to an extent that outweighs the energetic cost of sclerophylly (Turner, 1994). This hypothesis has been tested experimentally in lowland Amazonian white-sand forests by Fine et al. (2004, 2006). Several other recently described species from the sandstone plateaus of the Cordillera del Cóndor, such as Dacryodes uruts-kunchae Daly, M. C. Martínez \& D. A. Neill (Burseraceae), also have small, thick sclerophyllous leaves. There is a more thorough discussion of the adaptive advantage and evolution of sclerophylly in plants of that region in an article by Daly et al. (2012).

IUCN Red List category. Clethra concordia, although it occurs in two countries, is known from a single population with an area of occupancy of less than $20 \mathrm{~km}^{2}$, as far as is known. Although the population is not imminently threatened, it may be prone to unforeseen stochastic events such as a brush fire in a year of dry weather, or rapid climate change. Under these criteria (IUCN, 2001), this species should be listed in the IUCN category of Vulnerable (VU).

Etymology. The specific epithet "concordia" is a compound word from the Latin, translated literally as "with hearts" or "with hearts (working) together," and denoting harmony and peace. The epithet commemorates the peace accords and treaty signed by the presidents of Ecuador and Peru in 1998, and ratified by the respective legislatures of those countries, in the culmination of the diplomatic negotiations following the 1995 border dispute between the two countries, the War of Cenepa. Some of the heaviest fighting took place at this site in January to February 1995, and the armies of both Ecuador and Peru planted lethal land mines in the scrub vegetation on the Machinaza summit where Clethra concordia is locally common. After the 1998 treaty that established the international border once and for all, a path was cleared through the mine field in order to place an obelisk-shaped boundary marker, a hito in Spanish. Two of the authors of $C$. concordia represent the community of botanists of Peru and Ecuador, and we hope the name will serve as a reminder and hito of our peaceful bi-national collaboration in scientific endeavors. The epithet is also an anagram of "condorica," which denotes the geographical distribution of this species.

Discussion. The reduced stature and small, thick, coriaceous leaves of Clethra concordia are extremes within the genus, such that, based on vegetative characters, specimens of this taxon are not readily recognizable as Clethra, and for that reason, the original material collected in Peru in 1994 languished in the family indet cabinets in the herbarium of the Field Museum, Chicago, for a decade, until a look at the 3 -valved capsule triggered a flash of recognition in the mind of the senior author. Among its Andean congeners, C. concordia is mostly closely approached by $C$. ovalifolia Turcz., a species that ranges from Andean Venezuela to northern Peru (Sleumer, 1967; Gustafsson, 1992) in its shrubby stature and small, glabrous or glabrate leaves, but the 
leaves of the latter are at least $3 \mathrm{~cm}$ in length and are mostly 4-7 cm long, whereas those of $C$. concordia are $0.9-1.5(-1.8) \mathrm{cm}$ long. Some other species of Clethra are rather shrubby, including C. ovalifolia, but C. concordia is extreme in its short and diminutive stature, rarely more than $1.5 \mathrm{~m}$ tall, and often with a single unbranched stem or sparsely branched. The leaves of $C$. ovalifolia are usually uniformly serrate with very small serrations or sometimes nearly entire, whereas the leaves of $C$. concordia have fewer teeth that are longer and more prominent in relation to the size of the leaf, but only on the apical $1 / 3$ of the leaf margin. The inflorescence of $C$. concordia, like its congeners, is a terminal raceme, but in all other Neotropical species in Clethra sect. Cuellaria the racemes are clustered into rather dense fascicles or panicles, with at least three and usually five to eight racemes per fascicle, whereas in $C$. concordia the racemes are always solitary and strictly erect or sub-erect on erect branches.

Paratypes. ECUADOR. Zamora Chinchipe: Cordillera del Cóndor, Machinaza plateau, $2400 \mathrm{~m}$, same locality \& date as the type (fl.), D. Neill \& W. Quizhpe 16126 (LOJA, MO, QCNE), (fr.), D. Neill \& W. Quizhpe 16127 (LOJA, MO, QCNE). PERU. Amazonas: Condorcanqui, Cordillera del Cóndor, la cima del tepui Cerro Machinaza, cabeceras del Río Comainas, tributario al O del Río Cenepa; arriba de Puesto de Vigilancia Alfonso Ugarte (PV3), subiendo atrás y $\mathrm{N}$ del camp., $03^{\circ} 52^{\prime} 42^{\prime \prime} \mathrm{S}, 78^{\circ} 25^{\prime} 48^{\prime \prime} \mathrm{W}, 2160 \mathrm{~m}, 30$ July 1994 (fl., fr.), H. Beltrán \& R. Foster 1501 (F, MO, USM).

Acknowledgments. We thank Robin Foster for making available the 1994 Peruvian collections of this species at F, John Myers for the fine illustration, and Roy Gereau for help with the Latin diagnosis. The 1994 Peruvian collections were made during an expedition sponsored and financed by Conservation International (Schulenberg \& Awbrey, 1997). The 2008 Ecuadorian collections were made during fieldwork for an environmental impact study by Cardno Entrix, Inc. for Kinross Aurelian Corp. We thank the Ecuadorian military personnel at the Paquisha Alta post, who helped us reach the Machinaza plateau.

\section{Literature Cited}

Anderberg, A. A. \& Z. Zhang. 2002. Phylogenetic relationships of Cyrillaceae and Clethraceae (Ericales) with special emphasis on the genus Purdiaea. Organisms Diversity Evol. 2: 127-137.

Brako, L. \& J. L. Zarucchi. 1993. Catalogue of the Flowering Plants and Gymnosperms of Peru. Monogr. Syst. Bot. Missouri Bot. Gard. 45.

Daly, D. C., D. Neill \& M. C. Martínez-Habibe. 2012. An ecologically significant new species of Dacryodes from the northern Andes. Studies in Neotropical Burseraceae XV. Brittonia 64(1): 49-56.

Fine, P. V. A., I. Mesones \& P. D. Coley. 2004. Herbivores promote habitat specialization by trees in Amazonian forests. Science 305: 663-665.

Fine, P. V. A., Z. J. Miller, I. Mesones, S. Irazuzta, H. M. Appel, M. H. H. Stevens, I. Sääksjärvi, J. C. Schultz \& P. D. Coley. 2006. The growth-defense trade-off and habitat specialization by plants in Amazonian forests. Ecology 87(7) Suppl.: S150-S162.

Fior, S., P. O. Karis \& A. Anderberg. 2003. Phylogeny, taxonomy, and systematic position of Clethra (Clethraceae, Ericales) with notes on biogeography: Evidence from plastid and nuclear DNA sequences. Int. J. Pl. Sci. 164(6): 997-1006.

Gregory-Wodzicki, K. M. 2000. Uplift history of the central and northern Andes: A review. Geol. Soc. Amer. Bull. 112(7): 1091-1105.

Gustafsson, C. 1992. Clethraceae. Fl. Ecuador 45: 3-26.

Hamilton, C. W. 1985. Notes on and descriptions of seven new species of Mesoamerican Clethraceae. Ann. Missouri Bot. Gard. 72: 539-543.

IUCN. 2001. IUCN Red List Categories and Criteria, Version 3.1. Prepared by the IUCN Species Survival Commission. IUCN, Gland, Switzerland, and Cambridge, United Kingdom.

Neill, D. A. 2005. Cordillera del Cóndor: Botanical treasures between the Andes and the Amazon. Pl. Talk 41: 17-21.

Rogers, Z. S. 2002a. A new species of Weinmannia (Cunoniaceae: Cunonieae) from southern Ecuador. Novon 12(2): 249-252.

Rogers, Z. S. 2002b. Two new species of Weinmannia (Cunoniaceae: Cunonieae) from southern Ecuador. Sida 20(1): 179-187.

Schulenberg, T. S. \& K. Awbrey (editors). 1997. The Cordillera del Cóndor region of Ecuador: A biological assessment. RAP Working Papers 7: 1-231.

Sleumer, H. 1967. Monographia Clethracearum. Bot. Jahrb. Syst. 87: 36-116.

Turner, I. M. 1994. Sclerophylly: Primarily protective? Funct. Ecol. 8: 669-675. 


\section{$2 \mathrm{BHL}$ Biodiversity Heritage Library}

Neill, David A, Beltrán Santiago, Hamilton, and Quizhpe, Wilson. 2012. "Clethra concordia (Clethraceae), a Shrubby New Species from the Crest of the Cordillera del Cóndor on the Peru-Ecuador Border." Novon a journal of botanical nomenclature from the Missouri Botanical Garden 22(2), 212-216. https://doi.org/10.3417/2009038.

View This Item Online: https://www.biodiversitylibrary.org/item/196082

DOI: https://doi.org/10.3417/2009038

Permalink: https://www.biodiversitylibrary.org/partpdf/218560

\section{Holding Institution}

Missouri Botanical Garden, Peter H. Raven Library

\section{Sponsored by}

Missouri Botanical Garden

\section{Copyright \& Reuse}

Copyright Status: Permission to digitize granted by rights holder

Rights: https://www.biodiversitylibrary.org/permissions

This document was created from content at the Biodiversity Heritage Library, the world's largest open access digital library for biodiversity literature and archives. Visit BHL at https://www.biodiversitylibrary.org. 